\title{
PENGEMBANGAN BAHAN AJAR INTERAKTIF DENGAN MENGGUNAKAN APLIKASI LECTORA INSPIRE UNTUK MAHASISWA PENDIDIKAN BAHASA DAN SASTRA INDONESIA
}

\author{
Prasetyo Yuli Kurniawan \\ Program Studi Pendidikan Bahasa dan Sastra Indonesia, Universitas Muhadi Setiabudi \\ Email: prasetyoyulikurniawan@gmail.com
}

\begin{abstract}
Abstrak
Tujuan penelitian yaitu mendeskripsi kebutuhan berdasarkan perse psi do sen dan mahasis wa tentang pengembangan bahan dan mengidentifikasi uji validasibahan ajar. Metode penelitia $n$ ini yaitu penelitian dan pengembangan (Research and Development). Tahapan penelitian ini mengadaptasi dari Borg and Gallyang dilaksanakandalam beberapa tahap yaitu tahap awal pengembangan, tahap pengembangan, dan tahapuji. Prosedur pengumpulan data pada tahap a wal pengembangan menggunakan teknik wawancara, angket, dan dokumentasi. Sedangkan pengumpulan data pada tahap uji menggunakan teknik angket dan teknik te s. Teknik angket digunakan untuk menila ibahan ajar interaktif oleh validator. Teknik analisis da ta terdiri at a s tiga bagian yaitu pertama, teknik a nalisis kebutuhan bahan a jar y ang dip eroleh dari hasil a ngket kebutuhan mahasiswa dan dosen dianalisis dengan mengelompokkan, menyelesi, dan menyimpulk an data dari hasil pengisian a ngket kebutuhan. Kedua, teknik analisis da ta uji validasi dia nalisis da lam skor hasil va lidasi dari rentang 10 - 100 dan penyimpulan kategori beru pa baik, cukup, atau kurang. Hasil penelitian tentang analisis kebutuhan pengembangan bahan ajar berdasarkan persepsi dosen dan mahasiswa su dah memenuhi kebu tuhan dengan prosentasi terbesar. Kemudian draf bahan ajar sudah disesuaikan dengan kebutuhan persepsi do sen dan mahasiswa. Berdasarkan uji va lidasi menerangkan bahwa bahan ajar interaktif memeroleh skor 81 (kategoribaik).
\end{abstract}

Kata kunci:penelitian pengembangan, lectora inspire, bahan ajar interaktif.

\section{Abstract}

The purpose of the research was to describe the needs based on the perception of lecturers and students about material development andidentify validation tests of teaching materials. This research method is research and development. This stage of research adapts from Borg and Gall which is carried out in several stages, namely the early stages of development, the development stage, and the test phase. Data collection procedures in the early stag es of development using interview techniques, questionnaires, and documentation. While the data collection at the test stage using questionnaire techniques and test techniques. Questionnaire techniques are used to assess interactive teaching materials by validators. Data analysis techn ique consists of three parts, namely the first, the technique of analyzing the needs of teaching materials ob tained from the results of questionnaires needs of students and lecturers analyzed by grouping, completing, and concluding datafrom the results of filling the questionnaire needs. Second, the validation test data analysis technique is analyzed in validation resultscores from a range of $10-100$ and category inference is good, sufficient, or less. The results of research on the analysis of the need for the development of teaching materials based on the perception oflecturers and studen ts have met the needs with the greatest percentage. Then the draft teaching materials have been adapted to the perception needs of lecturers and students. Based on the validation test explained that interactive teaching materials get a score of 81 (good category).

Keywords: reseacrh and development, lectora inspire, interactive teaching materials.

\section{PENDAHULUAN}

Pada masa pandemi Covid-19 mengakibatkan dampak di semua bidang. Misalnya pada bidang ekonomi, pariwisata, dan pendidikan. Bukan hanya di Indonesia, dampak pandemi Covid-19 juga terjadi pada negara maju. Pada bidang pendidikan, dampak ini berakibat pada proses pembelajaran yang harus dilaksanakan dengan jarak jauh. Hal tersebut dilakukan untuk mencegah wabah virus menjangkit pembelajar 
baik di sekolah maupun perguruan tinggi. Kebijakan tersebut dipertegas dengan peraturan dari Kemdikbud dalam surat edaran No. 4 tahun 2020 tentang kebijakan pelaksanaan pembelajaran jarak jauh dalam asa pandemic Covid-19.

Di dalam kelas pada proses pembelajaran, pendidik harus mampu memberikan materi semenarik mungkin kepada peserta didik. Pembelajaran inovatif pada pandemi saat ini yaitu dengan menggunakan pembelajaran daring. Pembelajaran daring dilakukan dengan cara massif dan terbuka untuk memberikan pembelajaran yang bermutu (Adhe, 2018).

Berdasarkan beberapa survei di perguruan tinggi digunakan media daring media sosial, google classroom, dan aplikasi zoom. Media tersebut digunakan pada pelaksanaan perkuliahan jarak jauh. Pada dasarnya proses perkuliahan tersebut dilaksanakan untuk menekan penyebaran virus covid-19. Namun, esensi dalam perkuliahan belum seperti yang diharapkan. Terbukti dengan berbagai permasalahan di berbagai perguruan tinggi.

Berdasarkan observasi yang dilakukan, pembelajaran daring yang dilaksanakan di berbagai perguruan tinggi masih meninggalkan masalah. Misalnya pada perkuliahan di prodi Pendidikan Bahasa dan Sastra Indonesia. Masalah yang sering muncul yaitu timbul rasa bosan dan jenuh pada mahasiswa dalam mengikuti proses perkuliahan. Jika menggunakan google classroom maupun media sosial Whatsapp tidak ada interaksi antara dosen dan mahasiswa secara langsung sehingga mengakibatkan kejenuhan. Sedangkan dnegan Whatsapp hanya sekadar digunakan untuk memberikan tugas mahasiswa. Interaksi antara dosen dan mahasiswa dapat disiasati dengan menggunakan zoom meeting namun sarana seperti kuota tidak dapat memenuhi baik dari dosen dan mahasiswa selama satu semester penuh. Sehingga perlu adanya inovasi dan kreatif dari dosen dalam melaksanakan proses perkuliahan di kelas. Cara yang dapat dilakukan yaitu dengan membuat bahan ajar menarik dan inovatif.

Segala bahan yang disusun secara sistematis untuk pembelajaran merupakan arti dari bahan ajar (Prastowo, 2013:17). Bahan ajar perlu dikemas dengan kreatif dan inovatif yang berasal dari dosen perguruan tinggi. Sehingga perlunya dilakukan pelatihan dalam pengembangan bahan ajar. Pengembangan bahan ajar biasanya diberikan materi seperti: (1) penyusunan beberapa garis besar berdasarkan isi, (2) penulisan isi. (3) Perancangan ilustrasi dan tata letak (4) penggunaan bahasa bahan ajar yang baik, dan (5) pengintegrasian media audio dan video dalam bahan ajar yang disusun (Achmad, 2009).

Sebagai seorang dosen, harus memilih bahan ajar yang cocok dalam stiuasi dan kondisi. Bahan ajar seperti cetak, dengar (audio), bahan ajar dengar (audio visual), dan bahan ajar interaktif yang akan dikembangkan (Majid, 2008:173). Dosen harus dapat mengemas bahan ajar dengan tingkat kreativitasnya. Sehingga bahan ajar menjadi satu upaya untuk membuat perkuliahan semakin menyenangkan bagi mahasiswa. Dalam bahan ajar interaktif dapat disisipkan video interaktif. Video tersebut dapat penjelasan dosen mengenai materi tertentu. Menu-menu juga dapat diakses dengan mudah. Sehingga dosen harus dapat membuat bahan ajar dengan bantuan software tertentu. Salah satu yang dapat dimanfaatkan yaitu aplikasi Lectora Inspire.

Lectora Inspire menjadi salah satu tools atau alat pengembangan pembelajaran elektronik atau daring. Software ini pada tahun 1999 dikembangkan oleh Timothy D. Loudermik dengan nama perusahaan Trivantis Corporation. Lectora Inspire sangat mudah digunakan oleh pendidik atau guru yang akan menggunakannya sebagai pembuat bahan ajar interaktif. Lectora Inspire dapat digunakan sesuai kebutuhan baik secara daring maupun luring (offline). Dalam aplikasi ini sudah banyak disediakan template yang siap digunakan untuk memasukan materi pembelajaran. Selain itu, dalam library aplikasi ini terdapat banyak gambar, animasi, dan akarakter yang dapat digunakan (Wulandari et al., 2017). Hasil yang diinginkan dari aplikasi ini yaitu HTML, standar e-learning SCORM dan AICC. Single File Executable (exe), dan CDROM.

Media pembelajaran yang dikemabngkan dengan software atau aplikasi Lectora Inspire sangat cocok digunakan oleh dosen. Hal tersebut karena minat belajar peserta didik atau mahasiswa dapat meningkat. Kemudian diiringi meningkatnya pemahaman materi yang disajikan menarik dalam bahan ajar (Purwendri, 2013). Sehingga aplikasi ini sangat layak digunakna untuk mengembangkan bahan ajar dan mengimplementasikan dalam kelas. (Mahmudah dan Pustikaningsih, 2019). 
Pembelajaran menggunakan bahan ajar interatif berbasis aplikasi Lectora Inspire sudah dikenal dalam dunia pendidikan. Dalam pendidikan sering memanfaatkan aplikasi ini sebagai penunjang peningkatkan nilai-nilai yang peserta didik pelajari. Hal ini dapat disimpulkan bahwa pembelajaran dengan pengembangan berbasis lectora inspire lebih signifikan dibanding buku yang ada di sekolah (Shalikhah, 2017). Hal tersebut menjadi inovasi yang dapat digunakan sebagai pembelajaran. Baik pembelajaran secara daring maupun pembelajaran secara luar daring.

Berdasarkan fenomena yang telah dijelaskan, penelitian ini urgen untuk dilakukan untuk menjawab permasalahan pembelajaran jarak jauh yang terjadi saat ini seperti bosan dan kejenuhan mahasiswa. Sehingga dapat disimpulkan penelitian ini yaitu "Pengembangan Bahan Ajar Interaktif dengan Menggunakan Lectora Inspire untuk Mahasiswa Pendidikan Bahasa dan Sastra Indonesia”.

\section{METODE PENELITIAN}

Metode penelitian yang digunakan yaitu penelitian pengembangan (research and development). Penelitian pengembangan biasanya digunakan dalam menghasilkan sesuatu produk tertentu. Selain itu juga perlu diuji bagaimana keefektifan produk itu (Sugiyono, 2012). Penelitian ini menghasilkan produk bahan ajar melalui proses pengembangan dengan bantuan aplikasi lectora inspire.

Borg dan Gall mengidentifikasi penelitian pengembangan yaitu mencakup 10 langkah. Namun, dalam penelitian ini hanya dilakukan sampai tahap uji validasi. Hal tersebut karena jika seluruh langkah dilakukan akan berdampak pada factor waktu dan biaya. Sehingga dalam penelitian ini mengadaptasi teori Borg and Gall menjadi 3 (tiga) tahap penelitian. Tahapan penelitian tersebut dapat dijelaskan sebagai berikut.

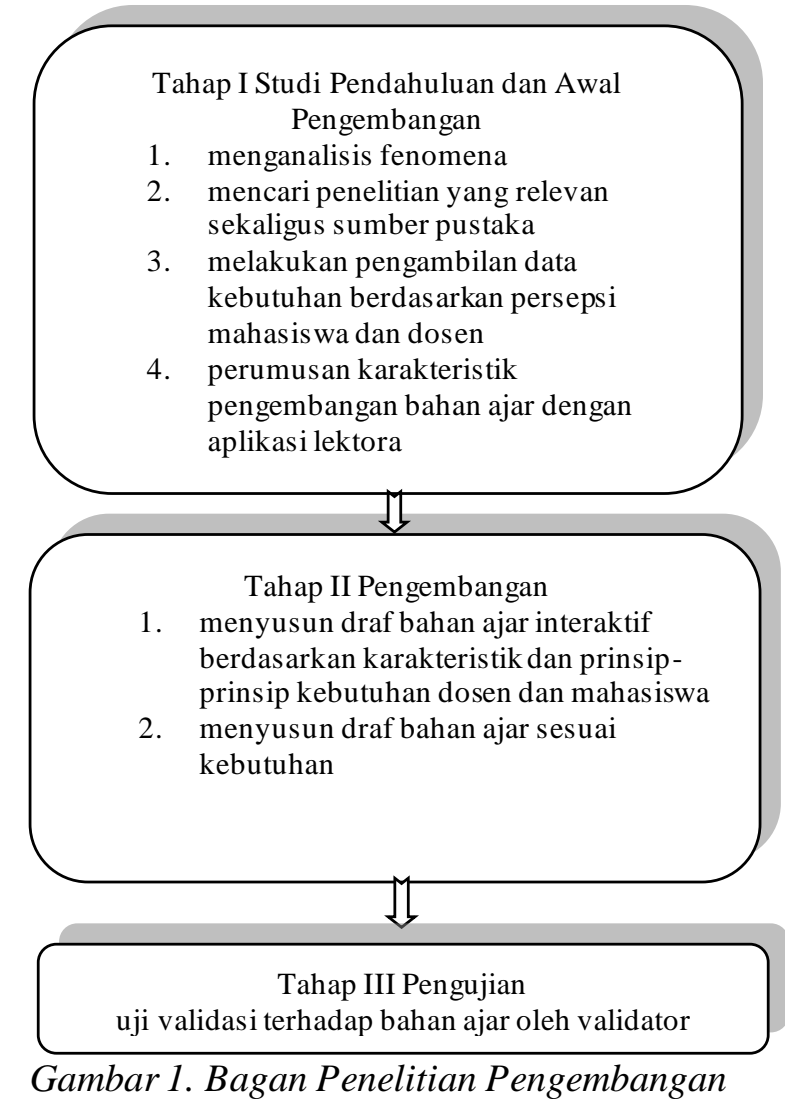

HASIL PENELITIAN

Hasil penelitian dalam pengembangan ini yaitu analisis kebutuhan bahan ajar dengan menggunakan aplikasi lektora inspire berdasarkan persepsi dosen dan mahasiswa, draf bahan ajar interaktif, dan uji validasi ahli terhadap bahan ajar yang dinilai oleh validator. Untuk lebih lengkapnya dijelaskan sebagai berikut.

\section{Analisis Kebutuhan Bahan Bahan Ajar Berdasarkan Persepsi Dosen dan Mahasiswa}

Hasil analisis kebutuhan yang dilakukan digunakan untuk mengembangkan bahan ajar menurut persepsi dosen dan mahasiswa. Berdasarkan persepsi dosen 3 perguruan tinggi yaitu Universitas Peradaban, Universitas Panca Sakti, dan Universitas Muhadi Setiabudi dapat disajikan dalam tabel berikut.

Tabel 1. Data Kebutuhan Berdasarkan Persepsi Dosen

\begin{tabular}{|c|c|c|c|}
\hline No & $\begin{array}{c}\text { Aspek Bahan } \\
\text { Ajar }\end{array}$ & Jawaban Angket & $\%$ \\
\hline \multirow{4}{*}{1} & \multirow{4}{*}{ Isi/Materi } & Sosial & 66,66 \\
\hline & & $\begin{array}{l}\text { Kombinasi dari beberapa } \\
\text { wujud }\end{array}$ & 100 \\
\hline & & Gambar, tulisan, suara & 66,66 \\
\hline & & $\begin{array}{l}\text { Setiap pembahasan dalam } \\
\text { materi }\end{array}$ & 100 \\
\hline
\end{tabular}


Volume 6 No. 1 METALINGUA

April 2021 Jurnal Pendidikan Bahasa dan Sastra Indonesia

\begin{tabular}{|c|c|c|c|}
\hline & & $\begin{array}{l}\text { Memuat materi yang } \\
\text { pokok dalam bahan ajar }\end{array}$ & 100 \\
\hline & & $\begin{array}{l}\text { Judul, materi kuliah, } \\
\text { evaluasi }\end{array}$ & 100 \\
\hline \multirow{7}{*}{2} & \multirow{7}{*}{ Penyajian } & $\begin{array}{l}\text { Terdapat ilustrasi pada } \\
\text { materi }\end{array}$ & 100 \\
\hline & & \begin{tabular}{|lll} 
Terdapat contoh dan \\
ilustrasi
\end{tabular} & 100 \\
\hline & & Pembukaan berupa menu & 100 \\
\hline & & $\begin{array}{l}\text { Latihan berupa evaluasi } \\
\text { melalui video }\end{array}$ & 100 \\
\hline & & Sapaan berupa Anda & 100 \\
\hline & & $\begin{array}{l}\text { Semantik: } \quad \text { Berbasis } \\
\text { kearifan lokal brebes }\end{array}$ & 100 \\
\hline & & $\begin{array}{l}\text { Bahan ajar berbentuk } \\
\text { audio-visual }\end{array}$ & 100 \\
\hline \multirow{3}{*}{3} & \multirow{3}{*}{ Kebahasaan } & Bahasa jelas dan baku & 100 \\
\hline & & Komunikasi dua arah & 66,66 \\
\hline & & $\begin{array}{l}\text { Santun dalam gaya } \\
\text { bahasa }\end{array}$ & 66,66 \\
\hline \multirow{7}{*}{4} & \multirow{7}{*}{ Kegrafikaan } & $\begin{array}{l}\text { Judul, tingkat perguruan } \\
\text { tinggi, semester, dan }\end{array}$ & 66,66 \\
\hline & & $\begin{array}{l}\text { Gambar kearifan lokal } \\
\text { Brebes }\end{array}$ & 100 \\
\hline & & Ukuran huruf 16 & 66,66 \\
\hline & & $\begin{array}{l}\text { Jenis huruf: Materi } \\
\text { semantik }\end{array}$ & 100 \\
\hline & & $\begin{array}{l}\text { background berwarna } \\
\text { biru putih }\end{array}$ & 66,66 \\
\hline & & $\begin{array}{l}\text { Gambar ada pada setiap } \\
\text { bagian }\end{array}$ & 100 \\
\hline & & $\begin{array}{l}\text { Halaman muka: gambar } \\
\text { dan judul }\end{array}$ & 100 \\
\hline
\end{tabular}

Melihat dari tabel 1 dapat disimpulkan bahwa data prosentase tersebut yang akan dijadikan acuan dalam penyusunan bahan ajar interaktif yang dihasilkan oleh aplikasi lektora inspire.

Pengembangan bahan ajar interaktif dengan menggunakan aplikasi lektora berdasarkan persepsi mahasiswa di Universitas Muhadi Setiabudi, Universitas Peradaban, dan Universitas Panca Sakti dengan jumlah total mahasiswa di tiga perguruan tinggi yaitu 75 mahasiswa dapat disajikan pada tabel berikut.

Tabel 2. Data Kebutuhan Berdasarkan Persepsi Mahasiswa

\begin{tabular}{|c|c|c|c|}
\hline No & $\begin{array}{c}\text { Aspek Bahan } \\
\text { Ajar }\end{array}$ & Jawaban Angket & $\%$ \\
\hline \multirow{6}{*}{1} & \multirow{6}{*}{ Isi/Materi } & Sosial & 93,33 \\
\hline & & $\begin{array}{l}\text { Kombinasi dari beberapa } \\
\text { wujud }\end{array}$ & 100 \\
\hline & & Gambar, tulisan, suara & 97,33 \\
\hline & & $\begin{array}{l}\text { Setiap pembahasan dalam } \\
\text { materi }\end{array}$ & 97,33 \\
\hline & & $\begin{array}{l}\text { Memuat materi yang } \\
\text { pokok dalam bahan ajar }\end{array}$ & 93,33 \\
\hline & & \begin{tabular}{|l} 
Judul, materi kuliah, \\
evaluasi
\end{tabular} & 90.66 \\
\hline
\end{tabular}

\begin{tabular}{|c|c|c|c|}
\hline \multirow{7}{*}{2} & \multirow{7}{*}{ Penyajian } & \begin{tabular}{|l} 
Terdapat ilustrasi pada \\
materi
\end{tabular} & 100 \\
\hline & & $\begin{array}{lll}\begin{array}{l}\text { Terdapat } \\
\text { ilustrasi }\end{array} & \text { contoh } & \text { dan } \\
\end{array}$ & 97,33 \\
\hline & & Pembukaan berupa menu & 97,33 \\
\hline & & $\begin{array}{l}\text { Latihan berupa evaluasi } \\
\text { melalui video }\end{array}$ & 90,66 \\
\hline & & Sapaan berupa Anda & 93,33 \\
\hline & & $\begin{array}{l}\text { Semantik: } \\
\text { kearifan lokal brebes }\end{array}$ & 100 \\
\hline & & $\begin{array}{l}\text { Bahan ajar berbentuk } \\
\text { audio-visual }\end{array}$ & 100 \\
\hline \multirow{3}{*}{3} & \multirow{3}{*}{ Kebahasaan } & Bahasa jelas dan baku & 97,33 \\
\hline & & Komunikasi dua arah & 97,33 \\
\hline & & $\begin{array}{l}\text { Santun dalam gaya } \\
\text { bahasa }\end{array}$ & 97,33 \\
\hline \multirow{7}{*}{4} & \multirow{7}{*}{ Kegrafikaan } & $\begin{array}{l}\text { Judul, tingkat perguruan } \\
\text { tinggi, semester, dan }\end{array}$ & 100 \\
\hline & & $\begin{array}{l}\text { Gambar kearifan lokal } \\
\text { Brebes }\end{array}$ & 100 \\
\hline & & Ukuran huruf 16 & 86,66 \\
\hline & & $\begin{array}{l}\text { Jenis huruf: Materi } \\
\text { semantik }\end{array}$ & 93,33 \\
\hline & & $\begin{array}{l}\text { background berwarna } \\
\text { biru putih }\end{array}$ & 100 \\
\hline & & $\begin{array}{l}\text { Gambar ada pada setiap } \\
\text { bagian }\end{array}$ & 100 \\
\hline & & $\begin{array}{l}\text { Halaman muka: gambar } \\
\text { dan judul }\end{array}$ & 100 \\
\hline
\end{tabular}

Melihat dari tabel 2. dapat disimpulkan bahwa berdasarkan persepsi mahasiswa yang ditujukan kepada 75 mahasiswa dengan prosentasi besar yang dijadikan acuan dalam pengembangan. Sehingga bahan ajar interaktif mengacu pada kebutuhan mahasiswa.

\section{Draf Bahan Ajar Interaktif}

Berdasarkan kebutuhan pengembangan bahan ajar dikembangkan dalam wujud bahan ajar. Struktur bahan ajar ini terdiri atas cover bahan ajar, bagian isi bahan ajar, dan bagian evaluasi bahan ajar.

\section{Cover Bahan Ajar}

Bagian cover bahan ajar terdiri atas cover bahan ajar yang terdapat judul bahan ajar, logo universitas dan logo dikti, dan yang terakhir yaitu nama penulis. Pada cover ini juga dimuatkan gambar ilustrasi yang berkaitan dengan kearifan lokal Brebes. Hal tersebut bertujuan untuk menunjukan kebutuhan bahan ajar yang dikehendaki oleh mahasiswa dan dosen. Cover bahan ajar dapat dilihat pada gambar berikut. 


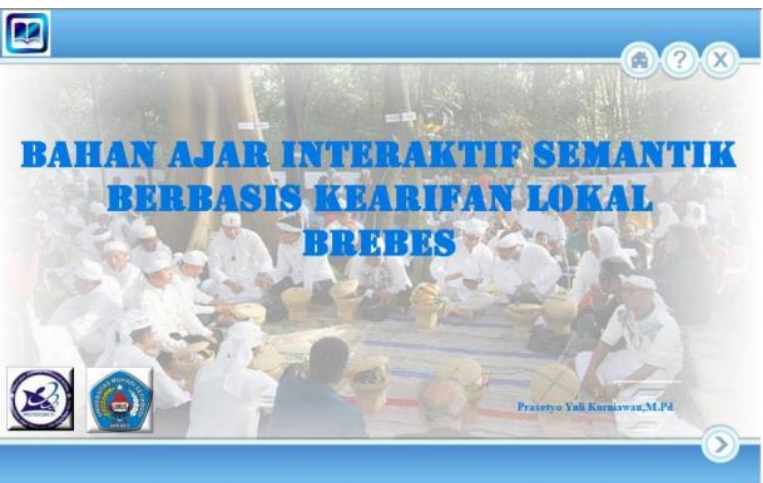

Gambar 2. Cover Bahan Ajar

\section{Isi Bahan Ajar}

Bagian isi bahan ajar terdiri atas lima menu utama. Menu tersebut yaitu berupa kontrak perkuliahan, materi kuliah, ujian semester, daftar pustaka, dan tentang penulis. Isi bahan ajar dapat dilihat pada gambar berikut.

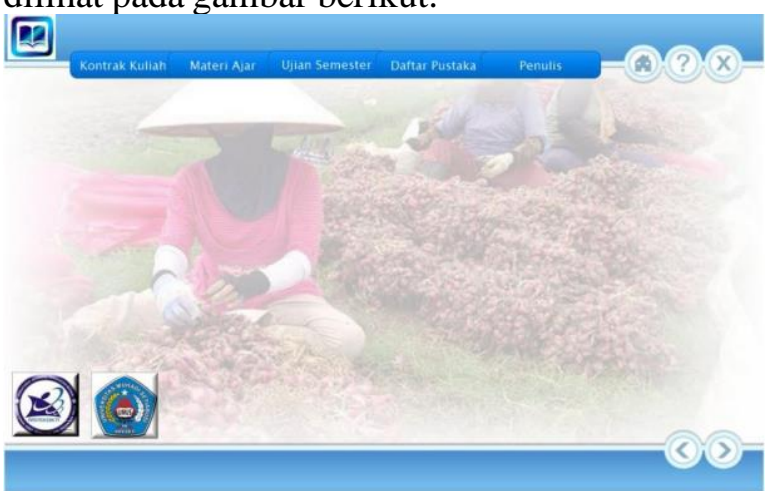

Gambar 3. Menu Isi Bahan Ajar

Pada menu kontrak perkuliahan jika ditekan akan mengarahkan pada sub menu yang baru. Pilihan tersebut yaitu deskripsi mata kuliah, tujuan umum perkuliahan, tujuan khusus perkuliahan, dan pertemuan pokok bahasan. Menu kotrak perkuliahan dapat disajikan pada gambar berikut.

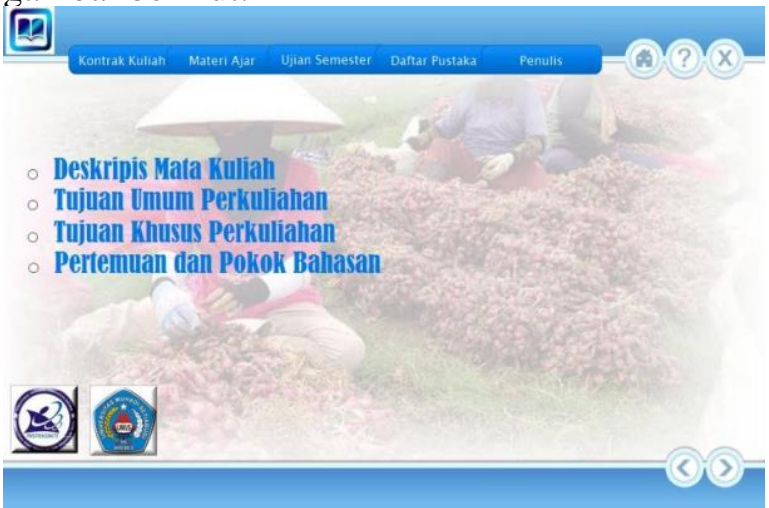

Gambar 4. Kontrak Perkuliahan Bahan Ajar
Pada menu materi ajar jika ditekan akan mengarahkan pada sub menu yang baru. Sub menu tersebut berupa materi perkuliahan yang akan diampu mahasiswa. Materi perkuliahan tersebut yaitu definisi semantik, bidang kajian semantik, unsur- unsur semantik, makna semantik, hiponimi, sinonimi, antonimi, polisemi, homonimi, homograf, homofon, dan ketaaksaan. Menu materi dapat dilihat pada gambar berikut.

\section{[0]}

Definisi Semantik
Bidang Kajian Semantik
- Unsur-unsur Semtantik
Makna Semantik
Hiponimi

\section{Sinonimi}

Antonimi

Polisemi

Homonimi, Monografi, Homofoni Ketaksaan (Ambiguitas)

\section{장 (요}

Gambar 5. Materi Perkuliahan Bahan Ajar

Pada menu ujian semester akan mengarahkan pada sub menu yang baru. Sub menu tersebut berupa ujian tengah semester (UTS) . Kemudian juga ada menu ujian akhir semester (UAS) yang dapat diakses mahasiswa. Menu tersebut dapat dilihat pada gambar berikut.
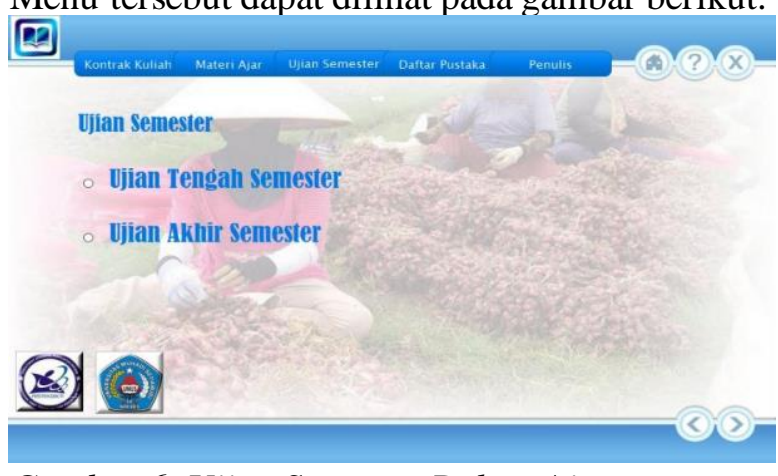

\section{Gambar 6. Ujian Semester Bahan Ajar}

\section{Bagian Evaluasi Bahan Ajar}

Pada bagian evaluasi terdiri atas dua jenis evaluasi. Evaluasi pertama berupa video interatif yang berkaitan tentang kearifan lokal Brebes. Evaluasi yang kedua berupa teks bacaan yang jug a masih berkaitan tentang kearifan lokal Brebes. Untuk lebih jelasnya perhatikan gambar berikut. 


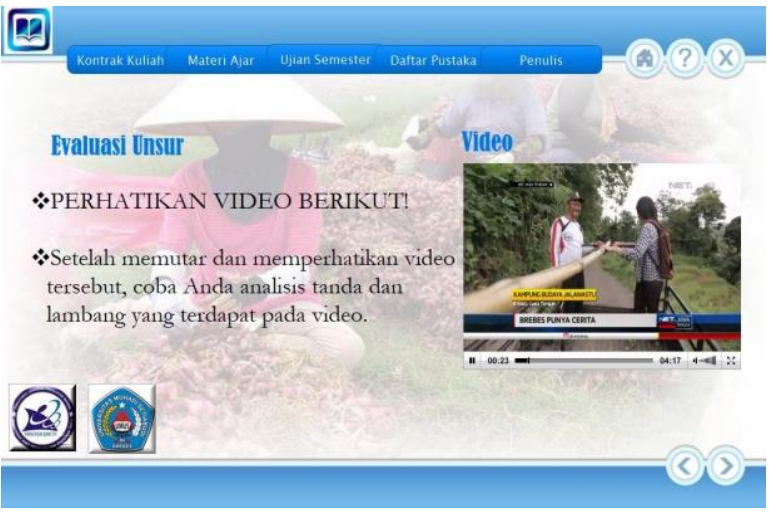

Gambar 7. Evaluasi Bahan Ajar dengan Video

\section{Uji Validasi Ahli}

Uji validasi dilakukan untuk mengetahui apakah bahan ajar layak atau tidak. Uji validasi dilakukan oleh validator yang ahli pada bidangnya. Ahli tersebut yaitu ahli kegrafikaan, ahli bahan ajar, dan ahli materi. Validator menilai bahan ajar dari isi atau materi, penyajian, kebahasaan, dan kegrafikaan. Untuk melihat hasil pengujian validasi bahan ajar dapat di lihat pada tabel berikut.

Tabel 3. Hasil Uji Validasi

\begin{tabular}{|c|l|c|c|}
\hline No. & $\begin{array}{c}\text { Aspek Bahan } \\
\text { Ajar }\end{array}$ & $\begin{array}{c}\text { Nilai dalam } \\
\mathbf{\%}\end{array}$ & Kategori \\
\hline 1. & Isi/Materi & 81 & Baik \\
\hline 2. & Penyajian & 83,5 & Baik \\
\hline 3. & Kebahasaan & 79 & Baik \\
\hline 4. & Kegrafikaan & 80,5 & Baik \\
\hline \multicolumn{2}{|c|}{ Rata-rata } & $\mathbf{8 1}$ & Baik \\
\hline
\end{tabular}

Melihat dari tabel 3 tentang hasil uji validasi ahli terhadap bahan ajar interaktif, maka dapat disimpulkan bahwa bahan ajar layak digunakan untuk perkuliahan. Hal tersebut didukung dengan data skor yaitu 81. Skor tersebut memiliki kategori baik. Sehingga pada kesempatan penelitian selanjutnya akan dilaksanakan uji keefektifan.

\section{SIMPULAN}

Kesimpulan dari penelitian ini yaitu berdasarkan data kebutuhan dosen dan mahasiswa bahwa bahan ajar interaktif sudah sesuai dengan kebutuhaan dengan responden 3 dosen dan 75 mahasiswa. Sehingga bahan ajar disusun dengan sistematis.

Draf bahan ajar sudah sesuai dengan standar kelayakan yaitu pada aspek materi, aspek penyajian, aspek kebahasaan, dan aspek kegrafikaan. Sehingga bahan ajar dapat disusun secara sistematis berdasarkan kebutuhan.
Pengembangan bahan ajar interaktif dengan menggunakan aplikasi lektora inspire dilaksanakan uji validasi ahli. Berdasarkan hasil rata-rata dari aspek isi, aspek penyajian, aspek kebahasaan, dan aspek kegrafikaan dapat disimpulkan bahwa perolehan skor akhir yaitu 81 dengan kategori penilaian baik.

\section{REFERENSI}

Achmad, Said Suhil. (2009). Pengantar Pengembangan Bahan Ajar di Perguruan Tinggi. Pekanbaru.

Majid, Abdul. (2008). Perencanaan Pembelajaran, Mengembangkan Standar Kompetensi Guru. Jakarta: PT. Rosda Karya.

Prastowo, Andi. 2013. Pengembangan Bahan Ajar Tematik. Diva PRESS: Yogyakarta.

Adhe, K. R. (2018). Pengembangan Media Pembelajaran Daring Matakuliah Kajian PAUD di Jurusan PG PAUD Fakultas Ilmu Pendidikan Universitas Negeri Surabaya. Journal of Early Childhood Care and Education, 1(1), 26. https://doi.org/10.26555/jecce.v1i1.3

Mahmudah, A., \& Pustikaningsih, A. (2019). Pengembangan Media Pembelajaran Interaktif Berbasis Lectora Inspire Pada Materi Jurnal Penyesuaian Untuk Siswa Kelas X Akuntansi Dan Keuangan Lembaga Smk Negeri 1 Tempel Tahun Ajaran 2018/2019. Jurnal Pendidikan Akuntansi Indonesia, 17(1), 97-111. https://doi.org/10.21831/jpai.v17i1.26515

Shalikhah, N. D. (2017). Media Pembelajaran Interaktif Lectora Inspire sebagai Inovasi Pembelajaran. Warta LPM, 20(1), 9-16. https://doi.org/10.23917/warta.v19i3.284 2

Sugiyono. (2012). Metode Penelitian Kuantitatif Kualitatif dan $R \& D$. Alfabeta.

Wulandari, B., Pd, M., Hasanah, N., Cs Satriyo, M., Dewanto, A., Muhammad, M. P., Mahali, I., \& Cs, M. (2017). Pembuatan Media Pembelajaran Dengan Lectora Inspire. 